Une nouvelle publication; Le Congo Pratique, journal mensuel publié à Léopoldville, vient de paraître; elle est fondée, dirigée et rédigée par des autochtones dans le but d'éduquer la masse et d'amener ses lecteurs à s'intéresser aux problèmes congolais et à tenter d'y apporter une solution pratique. Le journal est rédigé en français et en kikongo.

ANDRÉ SCOHY, Congopresse

\title{
Concours littéraire indigène: Bruxelles
}

EN I948, pour la première fois, fut organisé à Bruxelles, à l'occasion de la Foire coloniale, un concours littéraire réservé aux ouvrages écrits en français par des indigènes du Congo Belge et du Ruanda-Urundi. A ce concours, non moins de vingt manuscrits furent présentés : parmi eux, figurait $N g a n d 0^{\mathrm{I}}$ de Paul Lomami-Tshibamba, qui recueillit les suffrages unanimes du jury.

Avec Ngando, nous voyons enfin un écrivain congolais de langue française en possession de ses moyens et faisant ouvre originale. Ngando est un conte fantastique, une histoire d'occultisme africain où entrent dans une lutte farouche les forces du mal commandées par une vieille sorcière et les forces antagonistes maniées par un féticheur bénéfique.

La principale qualité du livre de Lomami-Tshibamba est d'avoir réussi à nous donner l'accès au monde magique dans lequel vivent et croient les Bantous. Ainsi, il a dépassé l'intérêt limité d'une histoire locale et, sans peut-être l'avoir voulu, il nous a donné une cuvre qui prend une portée universelle en se rattachant aux rythmes les plus anciens. Le livre de cet homme qui, atteint de surdité - il nous l'apprend lui-même dans la préface mène une vie retirée et méditative, échappe par là à l'écueil du régionalisme, et, ouvrant la voie à la jeune littérature congolaise, il prend, au même titre que la légende de Mélusine ou le Récit du Graal, une valeur de permanence dans le domaine de l'humain.

ANDRÉ SCOHY, Congopresse, no. 35

\section{Commonwealth Handbook ${ }^{2}$}

THE Royal Empire Society, London, has produced a pamphlet giving in a concise and readily accessible form information on all the official departments and independent societies and organizations in the United Kingdom concerned with British Dominion and Colonial territories. The items included are classified under Information and Publicity, Social Activities and Hospitality, Welfare, Emigration, Trade, Industry and Commerce, Agriculture and Forestry. The organizations concerned are divided into Departments of Government, Universities and Special Institutions, Empire and other societies. A list of specialist journals published in Great Britain is included.

\section{Literacy Campaign in Anglo-Egyptian Sudan}

A Literacy campaign is planned for Dueim on the White Nile, under the direction of a committee consisting of members of the Education Committee, Sheikh Mahgoub Abesher (Literacy Officer) and six others. Dueim town has been divided into six areas, in each of which a group will be formed to act as literacy unit for the area, the secretary of each group being a member of the committee. Volunteers who can read and write and are prepared to teach will be enlisted in each area, and will be shown the 'each one teach one' method and the use of the First Primer. A temporary shop for the sale of literary material and to serve as an information bureau and display centre will be opened.

I Ngando, par Paul Lomami-Tshibamba. Éditions Deny, 1946, avenue Carton de Wiart. Bruxelles. 1949. II 7 pages. 70 frs. belges.
2 Commonwealth Handbook, Royal Empire Society, Northumberland Avenue, London, 1949. Pp. 56. Is. $6 d$. 